\title{
Identification of a Tomatinase in the Tomato-Pathogenic Actinomycete Clavibacter michiganensis subsp. michiganensis NCPPB382
}

\author{
Olaf Kaup, Ines Gräfen, Eva-Maria Zellermann, Rudolf Eichenlaub, and Karl-Heinz Gartemann \\ Department of Genetechnology/Microbiology, University of Bielefeld, Universitaetsstr. 25, 33615 Bielefeld, Germany
}

Submitted 2 March 2005. Accepted 6 June 2005.

\begin{abstract}
The insertion site of a transposon mutant of Clavibacter michiganensis subsp. michiganensis NCPPB382 was cloned and found to be located in the gene $\operatorname{tom} A$ encoding a member of the glycosyl hydrolase family 10 . The intact gene was obtained from a cosmid library of $C$. michiganensis subsp. michiganensis. The deduced protein TomA (543 amino acids, $58 \mathrm{kDa}$ ) contains a predicted signal peptide and two domains, the $\mathrm{N}$-terminal catalytic domain and a $\mathrm{C}$-terminal fibronectin III-like domain. The closest well-characterized relatives of TomA were tomatinases from fungi involved in the detoxification of the tomato saponin $\alpha$-tomatine which acts as a growth inhibitor. Growth inhibition of $C$. michiganensis subsp. michiganensis by $\alpha$-tomatine was stronger in the $\operatorname{tom} A$ mutants than in the wild type. Tomatinase activity assayed by deglycosylation of $\alpha$-tomatine to tomatidine was demonstrated in concentrated culture supernatants of C. michiganensis subsp. michiganensis. No activity was found with the $\operatorname{tom} A$ mutants. However, neither the transposon mutant nor a second mutant constructed by gene disruption was affected in virulence on the tomato $\mathrm{cv}$. Moneymaker.
\end{abstract}

Clavibacter michiganensis subsp. michiganensis causes the bacterial wilt of tomato. After infection, C. michiganensis subsp. michiganensis NCPPB382 spreads systemically in the xylem of the plants. Various infections modes are described (Strider 1969): contaminated seed; natural or artificial wounds of roots, stems, or leaf trichomes; and infection through stomata. Infection through hydathodes also was observed (Carlton et al. 1998). The progressive disease leads to wilting and tissue macerations causing lesions of the infected stems (bacterial canker).

One of the plant defenses to which $C$. michiganensis subsp. michiganensis is exposed in the infected tomato plant is the production of saponines, consisting mainly of $\alpha$-tomatine and dehydrotomatine (Kozukue et al. 2004). $\alpha$-Tomatine is produced in all parts of the plant, but the content varies among different plant tissues, with the highest concentration in green fruit and leaves and the lowest in roots (Friedman and Levin 1998; Kozukue et al. 2004). The $\alpha$-tomatine content is further enhanced after recognition of pathogens by the plant (Arwijanato

Corresponding author: R. Eichenlaub; Telephone: 49-521-1065558; Fax: 49-521-1066015; E-mail: eichenlaub@uni-bielefeld.de

Nucleotide and amino acid sequence data is available from the GenBank database under accession number AF393183. et al. 1994; Smith and MacHardy 1982). $\alpha$-Tomatine inhibits fungal growth (Roldan-Arjona et al. 1999; Sandrock and VanEtten 1998), and inhibition of bacterial growth also has been observed (Arwiyanato et al. 1994; El-Shanshoury et al. 1995). The alkaloid $\alpha$-tomatine is composed of the steroidal aglycone tomatidine and the tetrasaccharide $\beta$-lycotetraose consisting of two glucose, one galactose, and one D-xylose residues (Fig. 1). For several species of fungi, detoxification mechanisms were described which involve the production of tomatinases of differing specificities that remove sugar moieties from $\alpha$-tomatine (Fig. 1) (Osbourn 1996; Quidde et al. 1998; Roldan-Arjona et al. 1999). In this study, we describe the identification of a bacterial tomatinase in the tomato pathogen $C$. michiganensis subsp. michiganensis.

\section{RESULTS}

Characterization of the transposon insertion site in a gene encoding a tomatinase.

After transposon mutagenesis of $C$. michiganensis subsp. michiganensis NCPPB382 using the artificial transposon Tn1409C $\beta$, which carries a chloramphenicol resistance gene cmx (Gartemann and Eichenlaub 2001), the insertion site of one mutant was characterized. From one of the first mutants obtained, the restriction fragments of $C$. michiganensis subsp. michiganensis $\mathrm{C} 7$ were cloned and sequence analysis of the resulting plasmids pKGT1040 and pTT1, containing the insertion site of $\operatorname{Tn} 1409 \mathrm{C} \beta$ (Fig. 2), revealed that the inactivated gene, designated tom $A$, encoded a member of family 10 of glycosyl hydrolases (Henrissat 1991). Most members of this family are endoxylanases. However, the best similarity obtained was to $\alpha$-tomatinases of Fusarium oxysporum $\mathrm{f}$. sp. lycopersic $i$ strains, also a vascular pathogen of tomato (Fig. 3). This fungal enzyme catalyses the removal of the complete tetrasaccharide lycotetraose of $\alpha$-tomatine (Roldan-Arjona et al. 1999).

In our cosmid library of $C$. michiganensis subsp. michiganensis, we identified tomA in the cosmid clone C2-28 by colony hybridization against a labeled tomA probe. Subclones of C228 termed pIG1 and pIG2 were constructed in pUC18 after hydrolysis with EcoRI and PstI (Fig. 2). The complete nucleotide sequence of the $6.1-\mathrm{kb}$ fragment represented by the inserts of these two plasmids was determined. Five open reading frames were identified. Only the $5^{\prime}$ part of the $\operatorname{reg} A$ gene was present, followed by $\operatorname{reg} B$ encoding a sensor kinase and a response regulator of a two-component regulatory system. The genes are located directly upstream of tomA. Downstream of tomA, the catR gene codes for a regulatory protein of 342 amino 
acids $(36 \mathrm{kDa})$, which is a member of the LacI-repressor family. Another gene, bglA, encodes a putative $\beta$-glucosidase (481 amino acids, $53 \mathrm{kDa}$ ) of unknown specificity.

The tomA gene codes for a putative tomatinase, a protein of 543 amino acids $(58 \mathrm{kDa})$. At the $\mathrm{N}$-terminus, there is a leader peptide (amino acids 1 to 27), indicating secretion of the protein. TomA has two domains, a catalytic domain (amino acids 28 to 340) and a second domain (amino acids 340 to 543), which exhibit weak similarity to PKD- or fibronectin III-like domains. The catalytic domain displays an identity or similarity of approximately 55 and $70 \%$ of the amino acids residues to the tomatinases of several Fusarium oxysporum strains and a protein from Aspergillus nidulans, respectively (Fig. 3). On the other hand, the identity or similarity values to the most closely related xylanases originating from bacteria are much lower, at approximately 35 and 50\%, respectively (Fig. 3), suggesting that tomA might encode a bacterial tomatinase.

The C-terminal fibronectin III-like domain is related to similar domains occurring in glycosyl hydrolases of bacteria (Howard et al. 2003; Saito et al. 2003; Zverlov et al. 1998). The exact function of the domain in these proteins is unknown. This putative fibronectin III-like domain is missing in both the

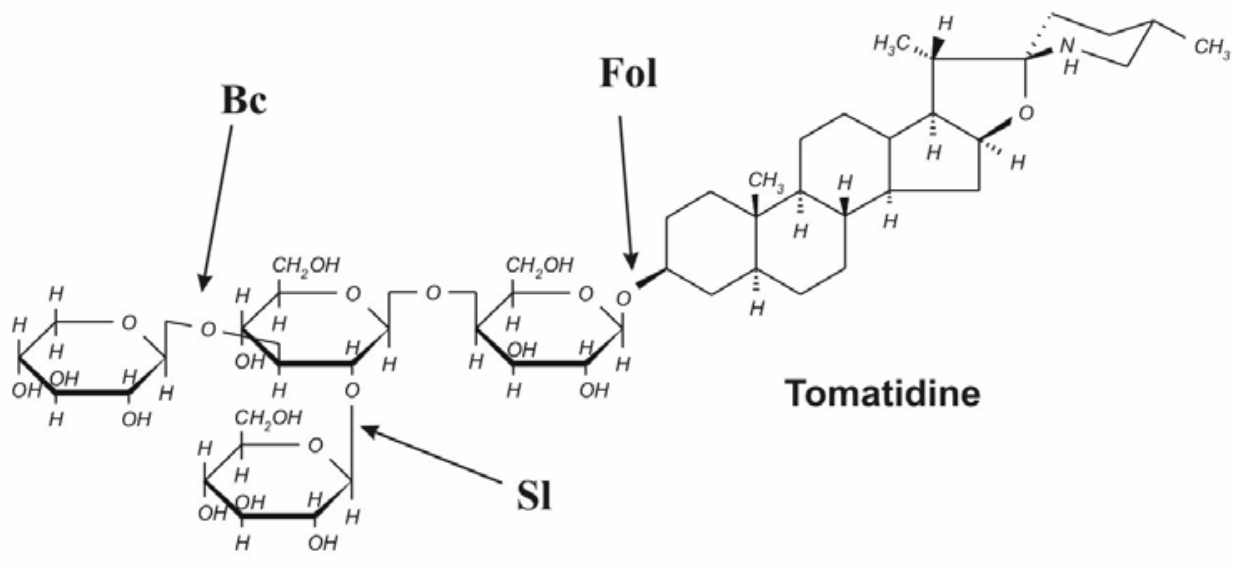

\section{Lycotetraose}

Fig. 1. Structure of $\alpha$-tomatine. The cleavage sites of the tomatinases from Fusarium oxysporum f. sp. lycopersici (Fol) (Roldan-Arjona et al. 1999), Septoria lycopersici (Sl) (Martin-Hernandez et al. 2000), and Botrytis cinerea (Bc) (Quidde et al. 1998) are indicated.

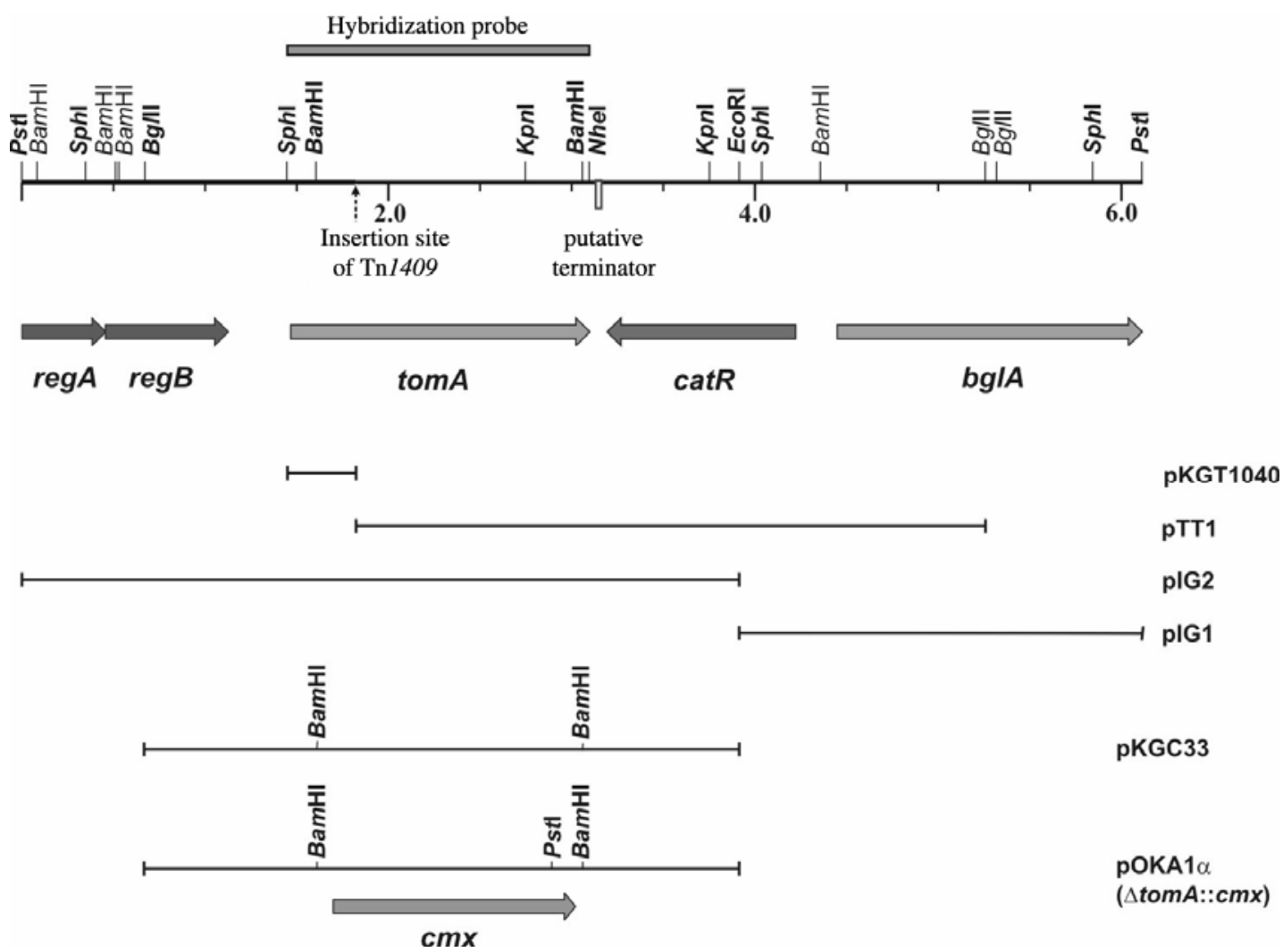

Fig. 2. Physical map of the chromosomal region carrying the tomA gene of Clavibacter michiganensis subsp. michiganensis NCPPB382. Genes and directions of transcription are represented by arrows. Bars indicate regions cloned into plasmids used in this study. The insertion site of Tn 1409 in the transposon mutant C. michiganensis subsp. michiganensis C7 is indicated. The second SphI, respectively, BglII site of pKGT1040 and pTT1, lies inside of Tn1409C and is not shown. The restriction sites given for pKGC33 and pOKA1 $\alpha$ are the sites used to insert the $c m x$ cassette. 
Cmm_TomA : MRTLTSAALATTVALGLTLIA-

Str-tur : MHRIG-AALAT-VTIGLLTVA-1-1

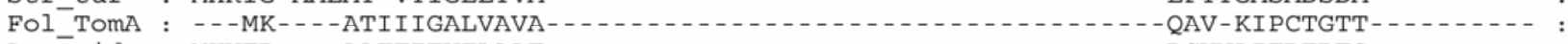

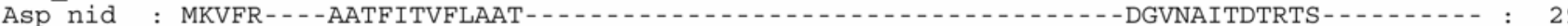

Ther_mar : -

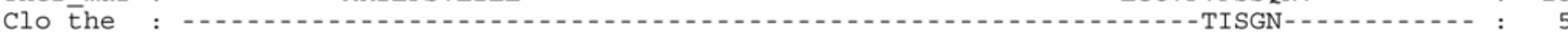

Fol_XY12 : MKLSSFLYTASLVAAIPTA-

Fol_XY13 : MHTFSVLLALAPVSALAQAPIWGQCGGNGWTGATTCASGLKCEKINDWYYQCVPGSGGSEPQPSSTQGGGTPQPTGGNSG : 80

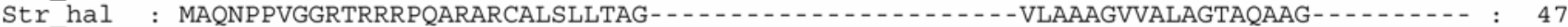
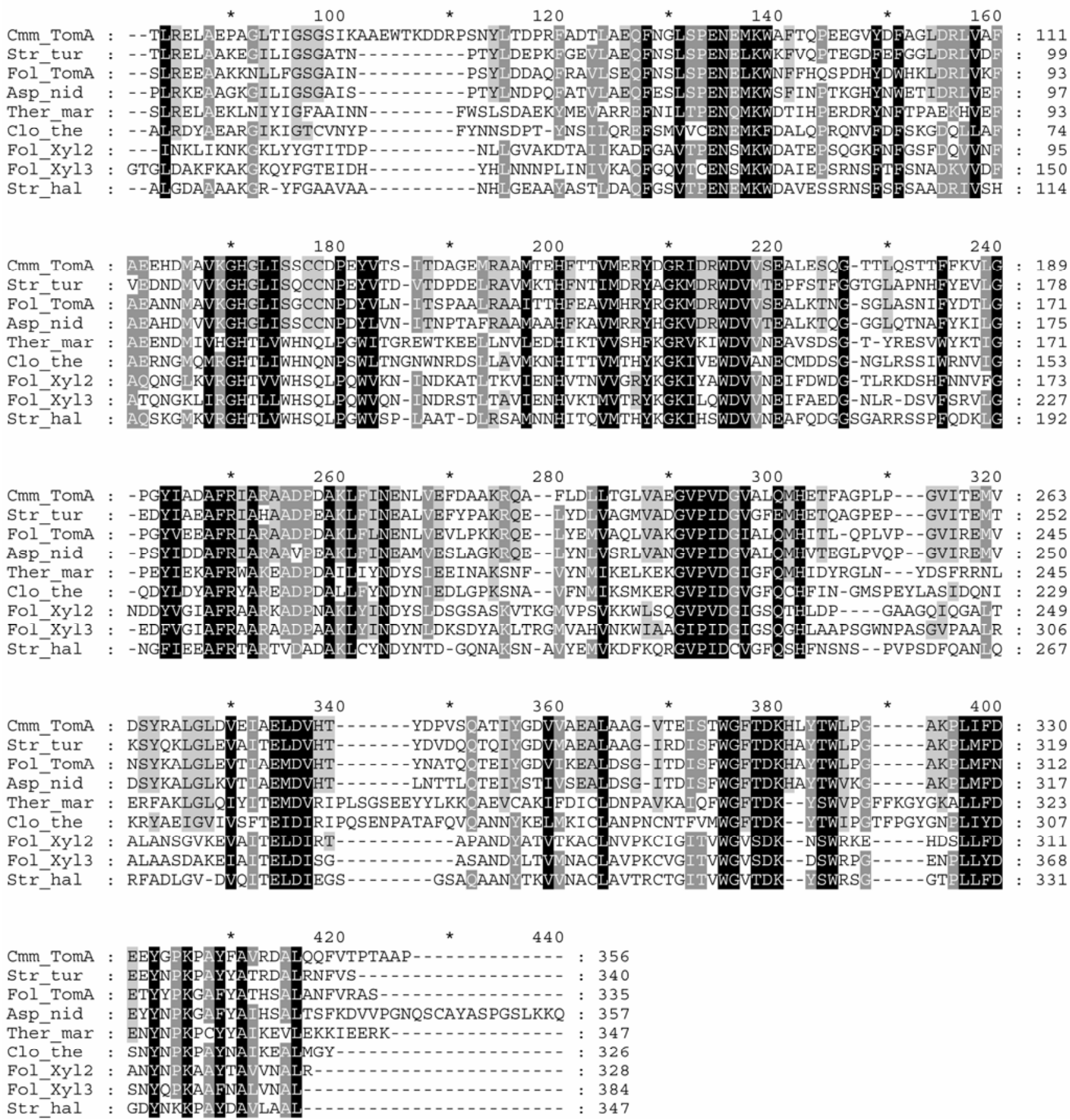

Fig. 3. Sequence comparison of the catalytic domain of TomA with various members of the glycosyl hydrolase family 10 . Amino acids identical in all the sequences of the tomatinase branch are boxed in light gray. Sequences used are: Cmm_TomA = tomatinase, N-terminal domain (amino acids 1 to 356; Clavibacter michiganensis subsp. michiganensis); Str_tur = putative tomatinase (amino acids 1 to 340, Streptomyces turgiscabies) (Kers et al. 2005); Fol_TomA = tomatinase (Fusarium oxysporum f. sp. lycopersici) (Roldan-Arjona et al. 1999); Asp_nid = hypothetical protein AN2356.2 (Aspergillus nidulans FGSC A4, accession number EAA64467); Ther_mar = endo-1,4- $\beta$-xylanase (Thermotoga maritima MSB8, AAD35164); Clo_the $=\beta-1,4-$-endoxylanase (amino acids 512 to 837; Clostridium thermocellum, ZP_00312306); Str_hal = xylanase, N-terminal domain (amino acids 1 to 347; Streptomyces halstedii, AAC45554); Fol_Xyl3 $=$ xylanase $($ F. oxysporum f. sp. lycopersici) $($ Ruiz-Roldan et al. 1999); Fol_Xyl2 = xylanase (F. oxysporum f. sp. lycopersici) $($ Ruiz-Roldan et al. 1999). 
tomatinase and the xylanases of F. oxysporum. Only the recently described tomatinase homolog from Streptomyces turgidiscabies (Kers et al. 2005) contains both domains in the same order as in $C$. michiganensis subsp. michiganensis, with high sequence similarity and identity of 58 and $71 \%$ of the amino acid residues, respectively, over the whole protein.

\section{Distribution of tomA in various $C$. michiganensis strains.}

Total DNAs of several $C$. michiganensis strains were probed for the presence of tomA using a 1.6-kb SphI/NheI digoxygenin-11-UTP-labeled probe derived from pIG2 (Fig. 2). With CMM100, a plasmid-free derivative of $C$. michiganensis subsp. michiganensis NCPPB382 (Meletzus and Eichenlaub 1991), a hybridization signal was obtained, demonstrating that tomA maps on the chromosome. All other $C$. michiganensis subsp. michiganensis strains tested also carry a tomA homolog, with the exception of NCPPB3264. No signal was obtained for the other Clavibacter subspecies, C. michiganensis subsp. sepedonicus (Solanum tuberosum), nebraskensis (Zea mais), tesselarius (Triticum aestivum), and insidiosus (Medicago sativa) (Fig. 4). Strains of the related plant pathogens Curtobacterium flaccumfaciens pv. oortii, three Rathayibacter spp., and Arthrobacter ilicis gave no positive signal with the tomA probe (data not shown).

\section{Insertional inactivation of tomA.}

In the course of the development of genetic procedures for Clavibacter michiganensis subsp. michiganensis, a second tomA mutant was constructed via gene replacement by substitution of a $1.5-\mathrm{kb}$ internal fragment of tomA with a chloramphenicol resistance gene. The 3.3-kb EcoRI/BglII fragment of pIG2 carrying tomA was cloned into pUC13 (pKGC33) and the BamHI fragment internal of tomA was replaced by the 1.5 $\mathrm{kb}$ BamHI fragment of pOKUCmB $\alpha$ carrying the $\mathrm{cm} x$ gene (Fig. 2). The resulting hybrid plasmid pOKA1 $\alpha$ carries both a large deletion inside of tomA and the selectable marker gene cmx in the same orientation as tomA. Chloramphenicol-resistant transformants were selected and replacement of the chromosomal tomA by the inactivated gene copy via homologous recombination was confirmed by Southern blot analysis (Fig. 5). The 3.9-kb EcoRI/PstI fragment from pIG2 was used as a tomA-specific hybridization probe. PstI-digested total DNA of C. michiganensis subsp. michiganensis NCPPB382 showed a single hybridizing restriction fragment of $6.1 \mathrm{~kb}$ when probed with the tomA-specific hybridization probe. Transformants in which the chromosomal tomA was replaced by double cross- over events have an additional PstI restriction site inside the cmx gene leading to two hybridizing signals of 2.9 and $3.2 \mathrm{~kb}$. To exclude the possibility that the whole suicide plasmid had integrated into the chromosome of $C$. michiganensis subsp. michiganensis, a hybridization against a pUC13 probe was conducted (data not shown). Thus, three tomA mutants (C. michiganensis subsp. michiganensis Tom2, Tom3, and Tom10) out of 20 chloramphenicol-resistant clones examined were obtained (Fig. 5). PstI-digested total DNA of the transposon mutant $C$. michiganensis subsp. michiganensis $\mathrm{C} 7$ gave two hybridizing restriction fragments of 2.3 and $4.4 \mathrm{~kb}$ when probed with the tomA-specific hybridization probe. The 3.4-kb transposon inserted in tomA carries five additional PstI restriction sites but only the Pst I fragments carrying the ends of the transposon $\left(0.5 \mathrm{~kb}\right.$ from the $5^{\prime}$ and $1.3 \mathrm{~kb}$ from the $3^{\prime}$ end of tomA) hybridize with the probe. This leads to fragments of 2.3 and $4.4 \mathrm{~kb}$ in length that show signals by Southern hybridization (Fig. 5).

Plasmid pCM2 of strain NCPPB382 is unstable; therefore, the tomA mutants (Tom2, Tom3, Tom10, and C7) were tested for their plasmid status. By Southern hybridization, it was

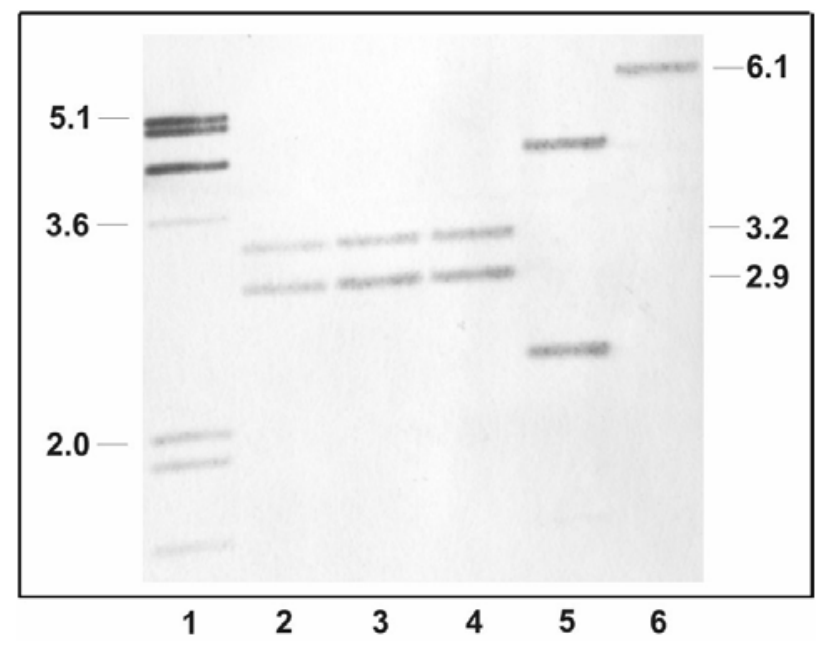

Fig. 5. Southern blot analysis of Clavibacter michiganensis subsp. michiganensis tomA mutants. PstI-digested total DNA of C. michiganensis subsp. michiganensis strains was hybridized against a 3.9-kb EcoRI/Pst $\mathrm{I}$ tomA probe. Lane 1, digoxygenin-labeled $\lambda$ EcoRI/HindIII; lanes 2 to 4, gene replacement mutants $C$. michiganensis subsp. michiganensis Tom2, Tom3, and Tom10, respectively; lane 5, transposon mutant C7; and lane 6, NCPPB382 (wild type).

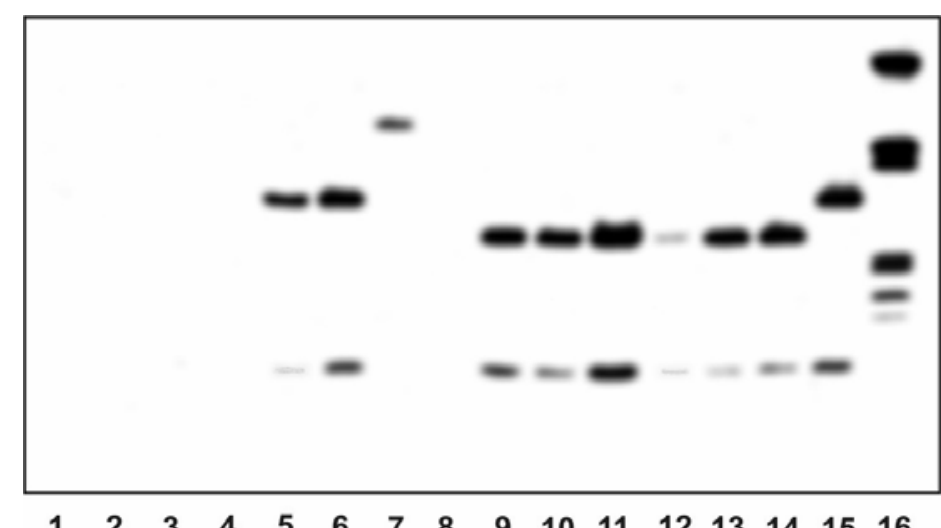

Fig. 4. Southern blot of total DNA of various Clavibacter michiganensis strains digested with $K p n I$ and hybridized against an internal 1.6-kb SphI/NheI-fragment of tomA. C. michiganensis subsp. and strains used were as follows. Lane 1: tesselarius ATCC33566; lane 2, insidiosus NCPPB1109; lane 3, nebraskensis NCPPB2526; lane 4: sepedonicus CS7; lane 5, CMM100; lane 6, michiganensis NCPPB382; lane 7, michiganensis C7; lane 8, michiganensis NCPPB3264; lane 9, michiganensis NCPPB2941; lane 10, michiganensis NCPPB2979; lane 11, michiganensis NCPPB3342; lane 12, michiganensis NCPPB3123; lane 13, michiganensis NCPPB1574; lane 14, michiganensis NCPPB2943; lane 15, michiganensis LMG5602; and lane 16, digoxygenin-labeled $\lambda$ EcoRI/HindIII. 
shown that all the mutants carried only plasmid pCM1 with the pathogenicity gene celA (Jahr et al. 2000) (data not shown). Thus, strain CMM101, which also carries only pCM1, was used as a control in plant assays which were performed to determine whether TomA is affecting virulence. Infection of tomato plants with the tomA gene replacement mutants (Tom2, Tom3, and Tom10) and the transposon mutant (C7) did not show any significant differences in the extent of virulence compared with CMM101. The wilting index determined by three independent tests was $14.1 \pm 1.0$ days for the tomA mutants and did not differ significantly from the control strain CMM101 with $14.3 \pm 0.9$ days. Also, the bacterial titer in planta of the tomA mutants $\left(7.24 \pm 4.30 \times 10^{9} \mathrm{CFU} / \mathrm{g}\right.$ of plant homogenate) 28 days after infection was in the same range as for the wild-type control, CMM101 $\left(5.70 \pm 2.14 \times 10^{9} \mathrm{CFU} / \mathrm{g}\right.$ of plant homogenate). This indicates that, in the interaction with the tomato cv. Moneymaker, tomA is not a virulence factor.

\section{Determination of tomatinase activity.}

Because we were unable to demonstrate an effect of tomA on virulence, it was necessary to show that $\operatorname{tom} A$ really encodes a tomatinase. The tomatinase-deficient mutants $C$. michigan- ensis subsp. michiganensis Tom2 (gene replacement mutant) and C7 (transposon mutant) and the wild-type strain CMM101 were grown in TBY (tryptone at $10 \mathrm{~g} /$ liter, yeast extract at 5 $\mathrm{g} /$ liter, $\mathrm{NaCl}$ at $5 \mathrm{~g} /$ liter, $\mathrm{pH}$ 7.5) containing $0.02 \mathrm{mM} \alpha$-tomatine. Both culture supernatants and crude protein extracts of these strains were tested for their ability to deglycosylate $\alpha$-to-

Table 1. Inhibition of growth of Clavibacter michiganensis subsp. michiganensis by $\alpha$-tomatine ${ }^{\mathrm{a}}$

\begin{tabular}{|c|c|c|c|}
\hline \multirow[b]{2}{*}{$\alpha$-Tomatine ( $\mu \mathrm{mol})$} & \multicolumn{2}{|c|}{ Inhibition zone diameter $(\mathbf{m m})$} & \multirow[b]{2}{*}{ Inhibition (\%) } \\
\hline & CMM101 $^{\text {b }}$ & $\operatorname{Tom}^{\mathrm{b}}$ & \\
\hline \multicolumn{4}{|l|}{$0^{\mathrm{d}}$} \\
\hline 0.05 & $6.0 \pm 0$ & $6.8 \pm 0.4$ & 12.5 \\
\hline 0.10 & $7.6 \pm 0.7$ & $11.0 \pm 0.4$ & 45.1 \\
\hline 0.20 & $11.6 \pm 0.5$ & $17.3 \pm 0.4$ & 49.0 \\
\hline 0.30 & $15.1 \pm 0.6$ & $22.7 \pm 1.0$ & 50.3 \\
\hline
\end{tabular}

${ }^{a}$ Means and standard deviations are from five independent assays.

${ }^{\mathrm{b}}$ CMM101, pCM1; Tom2, pCM1, tomA gene replacement mutant.

${ }^{c}$ Increase of inhibition. Given is the percentage by which the growth inhibition in the mutant is higher.

${ }^{\mathrm{d}}$ Control: Na-citrate buffer.

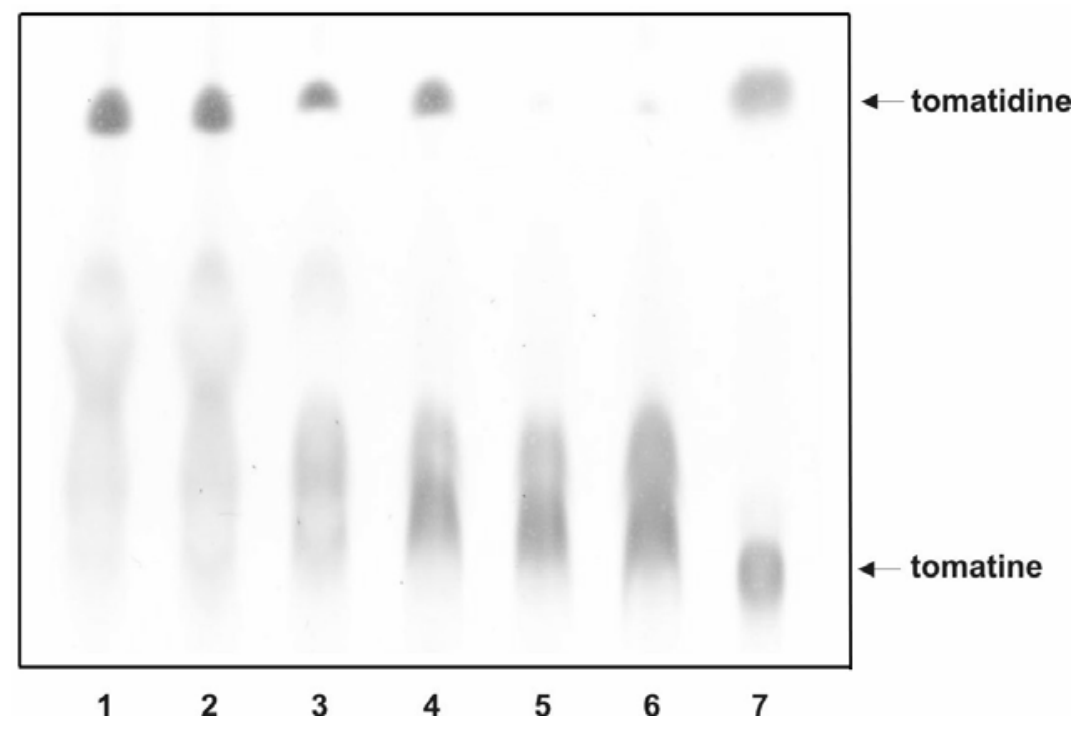

Fig. 6. Thin-layer chromatography analysis of tomatinase reaction products. Supernatants and crude protein extracts from Clavibacter michiganensis subsp. michiganensis strains were tested for $\alpha$-tomatine degradation. Lane 1 to 3 , crude extracts from CMM101 (wild type), C. michiganensis subsp. michiganensis Tom2, and C7, respectively; lanes 4 to 6, concentrated supernatants from CMM101 (wild type), Tom2, and C7, respectively; lane 7, mixture of $0.1 \mathrm{mM} \alpha-$ tomatine and tomatidine.
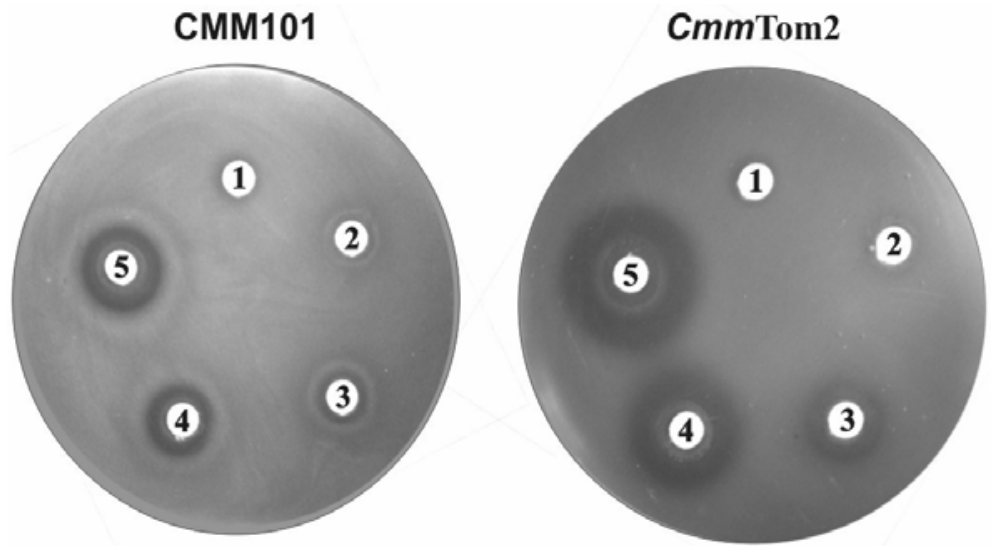

Fig. 7. Growth inhibition of $\alpha$-tomatine in an agar plate diffusion assay. Paper disks contain Na-citrate buffer (control $=1$ ), or increasing amounts of $\alpha$ tomatine $(2=0.05 \mu \mathrm{mol}, 3=0.1 \mu \mathrm{mol}, 4=0.2 \mu \mathrm{mol}, 5=0.3 \mu \mathrm{mol})$ dissolved in Na-citrate buffer. 
matine by thin-layer chromatography (TLC) analysis (Fig. 6). In the supernatant of strain CMM101 carrying the wild-type tomA gene, we found tomatinase activity with conversion of $\alpha$ tomatine to tomatidine, indicating that the enzyme was secreted and that tomatinase removes the complete lycotetraose from $\alpha$ tomatine. Thus, TomA seems to have the same activity as the homologous tomatinase from $F$. oxysporum, which carries out the same reaction producing tomatidine (Roldan-Arjona et al. 1999). Supernatants of both tomA mutants did not show any tomatinase activity. $C$. michiganensis subsp. michiganensis NCPPB382 showed the same degrading $\alpha$-tomatine activity in TLC experiments as CMM101 (data not shown).

Interestingly, crude protein extracts from mutants and CMM101 had a deglycosylation activity converting $\alpha$-tomatine to tomatidine. This degradation probably is caused by unspecific glycosidases present in the cytoplasm of C. michiganensis subsp. michiganensis.

\section{Inhibition of bacterial growth by $\alpha$-tomatine.}

Finally, we tested whether $\alpha$-tomatine has an inhibitory effect on growth of $C$. michiganensis subsp. michiganensis. In diffusion tests on agar plates with $\alpha$-tomatine $(0.05$ to $0.3 \mu \mathrm{mol})$, both mutants, Tom 2 and $\mathrm{C} 7$, were found to be more sensitive to $\alpha$-tomatine than the control strain CMM101. Both wild-type and mutants showed almost no inhibition of growth in the buffer control and with $0.05 \mu \mathrm{mol} \alpha$-tomatine. For higher concentrations of $\alpha$-tomatine, a concentration-dependant increase in growth inhibition was observed for all strains. Compared with the control strain CMM101, the mutants were affected much more strongly (Table 1; Fig. 7). For $\alpha$-tomatine at 0.1 $\mu \mathrm{mol}$, the growth inhibition zone of the gene replacement mutant was approximately $45 \%$ larger and, at $0.3 \mu \mathrm{mol}$, the highest concentration of $\alpha$-tomatine tested, the inhibition zone was approximately $50 \%$ larger than the corresponding ones of strain CMM101 (Fig. 7). This indicates that growth inhibition of $C$. michiganensis subsp. michiganensis caused by $\alpha$-tomatine occurs and that TomA can detoxify $\alpha$-tomatine. As in noninfected tomato plants of cv. Moneymaker, the content of $\alpha$-tomatine is approximately $775 \mathrm{nmol} / \mathrm{g}$ of fresh weight (Beimen et al. 1992), the amounts of $\alpha$-tomatine used in the inhibition test (50 to $300 \mathrm{nmol}$ ) cover the physiological relevant range.

To determine the inhibitory concentration of $\alpha$-tomatine more precisely, $C$. michiganensis subsp. michiganensis was grown in liquid TBY medium with different $\alpha$-tomatine concentrations. However, because both wild-type and tomA mutants formed large aggregates when $\alpha$-tomatine was present in concentrations above $0.2 \mathrm{mM}$, it was impossible to determine exact bacterial titers. Bacterial aggregation may be due to the production of polysaccharides, which has to be investigated in future work.

\section{DISCUSSION}

Here we describe the identification of a bacterial tomatinase involved in the detoxification of $\alpha$-tomatine, a phytoanticipin produced by tomato as a defense against pathogen infection.

The toxicity of $\alpha$-tomatine against $C$. michiganensis subsp. michiganensis could be demonstrated, which agrees with

Table 2. Bacterial strains and plasmids used in this study

\begin{tabular}{|c|c|c|}
\hline Strain or plasmid & Relevant characteristics $^{a}$ & Reference or source $^{b}$ \\
\hline \multicolumn{3}{|l|}{ Strains } \\
\hline \multicolumn{3}{|l|}{ Clavibacter michiganensis } \\
\hline subsp. michiganensis $\mathrm{NCPPB} 382$ & pCM1, pCM2; virulent on tomato & NCPPB \\
\hline subsp. michiganensis CMM101 & Curing derivative of NCPPB 382 , pCM1, virulent on tomato & Meletzus and Eichenlaub 1991 \\
\hline subsp. michiganensis CMM100 & Curing derivative of NCPPB 382 , plasmid-free; avirulent on tomato & Meletzus and Eichenlaub 1991 \\
\hline subsp. michiganensis $\mathrm{Cmm} \mathrm{C} 7$ & pCM1; tom A containing a $\operatorname{Tn} 1409 \mathrm{C}$ insertion; $\mathrm{Cm}^{\mathrm{r}}$ & This work \\
\hline subsp. michiganensis CmmTom2 & pCM1; tom $A$ gene replacement mutant; $\mathrm{Cm}^{\mathrm{r}}$ & This work \\
\hline subsp. michiganensis NCPPB3264 & Highly virulent on tomato & NCPPB \\
\hline subsp. michiganensis NCPPB2979 & Virulent on tomato & NCPPB \\
\hline subsp. michiganensis NCPPB3342 & Virulent on tomato & NCPPB \\
\hline subsp. michiganensis NCPPB 3123 & Avirulent on tomato & NCPPB \\
\hline subsp. michiganensis NCPPB 1574 & Avirulent on tomato & NCPPB \\
\hline subsp. michiganensis NCPPB2941 & Virulent on Capsicum frutescens & NCPPB \\
\hline subsp. michiganensis NCPPB2943 & Virulent on Capsicum frutescens & NCPPB \\
\hline subsp. michiganensis LMG5602 & Virulent on Cyphomandra betacea & LMG \\
\hline subsp. sepedonicus $\mathrm{CS7}$ & Virulent on potato (Solanum tuberosum) & Laine et al. 1996 \\
\hline subsp. nebraskensis NCPPB2526 & Virulent on corn (Zea mays) & NCPPB \\
\hline subsp. insidiosus NCPPB1109 & Virulent on alfalfa (Medicago sativa) & NCPPB \\
\hline \multirow{2}{*}{$\begin{array}{l}\text { Subsp. tesselartus AICC } 33566 \\
\text { Escherichia coli JM109 }\end{array}$} & Virulent on wheat (Triticum aestivum) & ATCC \\
\hline & $\begin{array}{l}\text { recA1 endA1 thi hsdR17 supE44 relA1 } \Delta\left(\text { lac-proAB) gyrA96 } \mathrm{F}^{\prime}(\text { traD36 proAB }\right. \\
\left.\text { lacl }{ }^{+} \text {lacZ } \mathrm{M} 15\right)\end{array}$ & Yanisch-Perron et al. 1985 \\
\hline E. coli GM119 & $\mathrm{F}^{-}$dcm-6 dam-3 met $\beta 1$ galK2 galT22 lacY1 tsx-78 supE44 & W. Wackernagel \\
\hline E. coli NM554 & $\mathrm{F}^{-}$recA araD $\Delta($ ara,leu $) \Delta$ lacY galU galK hsr hsm ${ }^{+}$strA mcrA mcrB & Stratagene, La Jolla, CA, U.S.A. \\
\hline \multicolumn{3}{|c|}{ 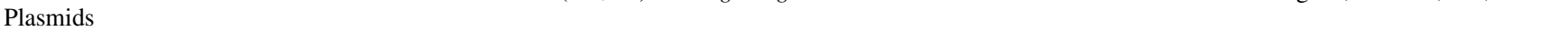 } \\
\hline pUC13 & Cloning vector; $\mathrm{Ap}^{\mathrm{r}}$ & Vieira and Messing 1982 \\
\hline pUC18 & Cloning vector; $\mathrm{Ap}^{\mathrm{r}}$ & Yanisch-Perron et al. 1985 \\
\hline pKGT452C $\beta$ & $\operatorname{Tn} 1409 \mathrm{C} \beta$; tnp $\mathrm{A}$ and $c m x$ in the same orientation & Gartemann and Eichenlaub 2001 \\
\hline pKGT1040 & pUC18::3.8-kb SphI fragment of mutant C7 & This work \\
\hline pTT1 & pUC13::5.5-kb $B g l I I$ fragment of mutant $\mathrm{C} 7$ & This work \\
\hline SuperCos1 & Cosmid; $\mathrm{Ap}^{\mathrm{r}}, \mathrm{Km}^{\mathrm{r}}$ & Stratagene \\
\hline $\mathrm{C} 2-28$ & SuperCos $1:: 35-\mathrm{kb}$ fragment of NCPPB382; tomA & This work \\
\hline pIG1 & pUC18::2.2-kb EcoRI/PstI fragment of C2-28 & This work \\
\hline pIG2 & pUC18::3.9-kb EcoRI/PstI fragment of C2-28; tomA & This work \\
\hline pOKU $9 \mathrm{cmB} \alpha$ & pUC18::1.5-kb BamHI fragment carrying $\mathrm{cm} x$ & This work \\
\hline pKGC33 & pUC13::3.3-kb BglIII/EcoRI fragment of pIG2, tomA; Ap ${ }^{\mathrm{r}}$ & This work \\
\hline pOKA $1 \alpha$ & pKGC33, cmx replacing the internal 1.5-kb BamHI-fragment of tomA; $\mathrm{Ap}^{\mathrm{r}}, \mathrm{Cm}^{\mathrm{r}}$ & This work \\
\hline
\end{tabular}

${ }^{\mathrm{a}} \mathrm{Ap}^{\mathrm{r}}=$ ampicillin resistance, $\mathrm{Cm}^{\mathrm{r}}=$ chloramphenicol resistance, and $\mathrm{Km}^{\mathrm{r}}=$ kanamycin resistance.

${ }^{\mathrm{b}}$ NCPPB = National Collection of Plant Pathogenic Bacteria, U.K.; LMG = Laboratorium voor Microbiologie, Gent, Belgium; ATCC = American Type Culture Collection, Manassas, VA, U.S.A.; W. Wackernagel, University of Oldenburg, Oldenburg, Germany. 
earlier reports on growth inhibition of bacteria by $\alpha$-tomatine (Arwiyanato et al. 1994; El-Shanshoury et al. 1995). The basis for this toxicity is unknown. For fungi, an interaction of $\alpha$-tomatine with membrane steroids leading to disruption of membranes is discussed (Osbourn 1996). Bacteria do not possess membrane steroids; therefore, a reason for toxicity against bacteria remains to be explained. The amphipatic nature of $\alpha$ tomatine, with its hydrophilic tetrasaccharide component and hydrophobic steroid-like aglycone, may allow insertion into the membrane. Because the $C$. michiganensis subsp. michiganensis tomatinase mutants were more sensitive to $\alpha$-tomatine than the control strain CMM101, a role of TomA in detoxification seems possible.

The tomatinase may facilitate invasion of plant tissues by $C$. michiganensis subsp. michiganensis; however, we find that the tomA mutants can infect and grow normally in the tomato cv. Moneymaker and are not reduced in virulence. Similar conflicting phenotypes were reported for fungi where a detoxification of $\alpha$-tomatine also occurs, but mutants are not or only slightly affected in virulence (Martin-Hernandez et al. 2000; Quidde et al. 1998). It is possible that, although the tomatinase is not important in cv. Moneymaker, it may be so in tomato cultivars which produce a larger amount of $\alpha$-tomatine. This seems to be the case especially in the related wild tomato species (e.g., Lycopersicon peruvianum and L. hirsutum) (Masahiro et al. 1996), which could represent a natural reservoir for virulent $C$. michiganensis subsp. michiganensis strains. The tomato cultivars developed for agricultural food production mostly have a low $\alpha$-tomatine content compared with wild tomato species (Masahiro et al. 1996). The amount of $\alpha$-tomatine present in Moneymaker (Beimen et al. 1992) is in the same range as reported for other cultivated tomato lines, which display a high variability in concentration among both races and different tissues (Friedman and Levin 1998; Kozukue et al. 2004; Osbourn 1996).

On the other hand, it may be possible that our infection method, which provides $C$. michiganensis subsp. michiganensis a direct access to the xylem where the $\alpha$-tomatine content is low, as long as no induction of $\alpha$-tomatine production due to recognition of the pathogen occurs (Smith and MacHardy 1982), circumvents this defense mechanism. Further studies, such as the comparison of virulence using tomato cultivars with higher $\alpha$-tomatine content and less drastic infection procedures, are required to give an answer to this question.

Interestingly, an entirely different function in pathogenic interaction may be ascribed to the tomatinase. It recently was reported by several groups that degradation products of $\alpha$-tomatine suppress induced plant defense mechanisms such as hypersensitive response (Bouarab et al. 2002; Ito et al. 2004). Thus, it is possible that the tomatinase is one of several factors which prevent plant defense in the $C$. michiganensis subsp. michiganensis-tomato interaction.

The catalytic domain of TomA belongs to family 10 of glycosyl hydrolases. We were able to demonstrate tomatinase activity for TomA. When comparing the sequences, a clear distinction between enzymes of proven endo-xylanase activity and enzymes closely related to TomA is seen. However, because some of these close relatives originate from organisms which are nonpathogenic (e.g., Aspergillus spp.) or have hosts which do not produce $\alpha$-tomatine (e.g., $S$. turgidiscabies), the substrate specificity of the enzyme remains interesting. Also, we cannot rule out that TomA has a cryptic xylanase activity. Therefore, we currently are trying to express TomA in Escherichia coli and to purify the protein, which will enable the determination of substrate specificity toward related alkaloids and xylan.

So far, we have no evidence that the neighboring $\operatorname{reg} A B$ and $c a t R$ genes are involved in the regulation of tomA. However, we are constructing mutants for these genes and will investigate a possible role for them in the future. Also, there is no indication that the putative $\beta$-glucosidase encoded by $b g l A$ is involved in $\alpha$-tomatine degradation because no leader peptide was predicted and the protein seems to be located in the cytoplasm.

\section{MATERIALS AND METHODS}

\section{Media and growth conditions.}

Bacterial strains and plasmids used and constructed in this study are listed in Table 2. E. coli was grown on TBY at $37^{\circ} \mathrm{C}$. Clavibacter strains were grown at $26^{\circ} \mathrm{C}$ on TBY. SB medium (tryptone at $10 \mathrm{~g} / \mathrm{liter}$, yeast extract at $5 \mathrm{~g} / \mathrm{liter}, \mathrm{NaCl}$ at 5 g/liter, $0.5 \mathrm{M}$ sorbitol, $20 \mathrm{mM} \mathrm{CaCl}_{2}, 20 \mathrm{mM} \mathrm{MgCl}_{2}$ ) was used for regeneration of $C$. michiganensis subsp. michiganensis after electroporation. For recombinant $E$. coli strains carrying pUC derivatives, ampicillin $(150 \mu \mathrm{g} / \mathrm{ml})$ or chloramphenicol (10 $\mu \mathrm{g} / \mathrm{ml}$ ) was added. Clavibacter strains bearing the $c m x$ gene were grown in the presence of chloramphenicol $(10 \mu \mathrm{g} / \mathrm{ml})$.

\section{DNA isolation, DNA manipulation, and DNA transfer.}

Plasmid DNA of E. coli was prepared by the alkaline lysis method (Sambrook et al. 1989). Plasmid DNA used for sequencing was isolated and purified by QIAGEN columns as specified by the manufacturer (Qiagen, Hilden, Germany). Preparation of total DNA for hybridization experiments and the construction of the cosmid library was done according to Hopwood and colleagues (1985). DNA restriction, fill-in reactions, ligation, and transformation were carried out following standard procedures (Sambrook et al. 1989). Isolation of restriction fragments from agarose gels was done with the JETSORB kit as specified by the manufacturer (Genomed, Bad Oeynhausen, Germany). Electroporation of $C$. michiganensis subsp. michiganensis was conducted as described by Kirchner and associates (2001) with the modification that only $1.25 \%$ glycine was used in the pretreatment of the cells.

\section{Insertional inactivation of the tom $A$ gene.}

pKGC33 contains only two BamHI restriction sites inside of tomA. After hydrolysis with BamHI, the $1.5-\mathrm{kb}$ internal tomA fragment was removed and replaced by a $1.5-\mathrm{kb}$ BamHI fragment from $\mathrm{pOKU} 9 \mathrm{cmB} \alpha$ which contains a $\operatorname{cmx}$ resistance gene. This resulted in the gene replacement vector pOKA1 $\alpha$ which contains the cmx resistance gene in the same orientation as tomA.

\section{Southern blot analysis.}

Probes for hybridization were isolated from agarose gels and labeled with digoxygenin-11-dUTP using the Random Primed DNA Labeling Kit (Roche Diagnostics, Mannheim, Germany). As a probe for the cmx gene (Tauch et al. 1998) specifying the chloramphenicol exporter, a 2.2-kb SphI/BglIIfragment of pKGT452C $\beta$ was used. The tomA gene was probed with the 1.6-kb SphI/NheI fragment of pIG2. Also, the 3.9-kb EcoRI/PstI fragment from pIG2 was used as a tomAspecific hybridization probe for identification of tomA gene replacement mutants. Digested chromosomal and plasmid DNA samples were separated on 0.7 to $1.0 \%$ agarose gels and transferred to a nylon membrane (porablot; Macherey \& Nagel, Düren, Germany) by capillary blots (Smith and Summers 1980). Hybridizations were carried out at $68^{\circ} \mathrm{C}$ overnight in a buffer containing $5 \times \mathrm{SSC}(1 \times \mathrm{SSC}$ is $0.15 \mathrm{M} \mathrm{NaCl}$ plus 0.015 M sodium citrate), $0.02 \%$ sodium dodecyl sulfate (SDS), $0.1 \%$ Na-laurylsarcosyl, and 2\% blocking reagent (Roche Diagnostics). The nylon membrane was washed twice in $0.1 \times \mathrm{SSC}$ and $0.1 \% \mathrm{SDS}$ at $68^{\circ} \mathrm{C}$ for $15 \mathrm{~min}$. Detection was carried out as recommended by the manufacturer (Roche Diagnostics). 


\section{DNA sequencing.}

For DNA sequencing, the dideoxy chain termination method (Sanger et al. 1977) was used. Sequencing was done by the IIT-Biotech GmbH (Bielefeld, Germany) using an ABI prism 377 apparatus (Applied Biosystems, Foster City, CA, U.S.A.). For sequencing, the plasmids pKGT1040, pTT1, pIG1, and pIG2 were used. The complete nucleotide sequence was determined by primer walking using synthetic oligonucleotide primers obtained from Sigma Genosys (Darmstadt, Germany). The overlap between pIG1 and pIG2 was obtained by sequences from pTT1. The DNA and deduced proteins sequences were compared with database entries using the BLAST programs (Altschul et al. 1997) at the server of the National Center of Biotechnology Information. Multiple sequence alignments were performed with ClustalX 1.83 (Thompson et al. 1994).

\section{Preparation}

of crude extracts and cell-free culture supernatants.

Overnight cultures of $C$. michiganensis subsp. michiganensis inoculated with single colonies and grown in TBY medium were diluted with fresh TBY medium to a final volume of $100 \mathrm{ml}$ with an optical density at $580 \mathrm{~nm}\left(\mathrm{OD}_{580}\right)$ of 0.7 to 0.9 . Then, $200 \mu \mathrm{l}$ of $10 \mathrm{mM} \alpha$-tomatine (dissolved in $50 \mathrm{mM}$ Na-citrate, $\mathrm{pH}$ 4.0) was added to a final concentration of $0.02 \mathrm{mM} \alpha$ tomatine. Incubation at $26^{\circ} \mathrm{C}$ was carried out for $6 \mathrm{~h}$. Bacteria were collected by centrifugation at $4,000 \times g$ for $10 \mathrm{~min}$. The cell pellet was resuspended in $2 \mathrm{ml}$ of PS-buffer $\left(\mathrm{Na}_{2} \mathrm{HPO}_{4}\right.$ at 7 $\mathrm{g} /$ liter, $\mathrm{NaCl}$ at $5 \mathrm{~g} /$ liter, $\mathrm{KH}_{2} \mathrm{PO}_{4}$ at $3 \mathrm{~g} /$ liter, $\mathrm{pH}$ 7.0).

The resuspended bacterial pellets were filled into a prechilled French press cylinder (AMINCO, Urbana, IL, U.S.A.) and mechanically disrupted by a pressure of approximately 17,000 psi. The procedure was repeated twice with the obtained lysate, followed by centrifugation for $30 \mathrm{~min}$ at $10,000 \times g$ to remove cell debris. The protein concentration of the cleared lysate was determined with the BCA Protein Assay Reagent (Pierce, Rockford, IL, U.S.A.) using bovine serum albumin as standard.

Cell-free supernatants were obtained by centrifugation at $4,000 \times g$ for $10 \mathrm{~min}$. The supernatants were transferred into dialysis tubes (10,000-Da cutoff) and dialyzed overnight against solid PEG 40,000 (polyethylene glycol) (Serva, Heidelberg, Germany) at $4^{\circ} \mathrm{C}$. Remaining PEG was removed by washing the dialysis tubes with distilled water. The PEGconcentrated samples then were dialyzed against distilled water for 1 to $2 \mathrm{~h}$ at $4{ }^{\circ} \mathrm{C}$. Up to 10 -fold concentration was achieved. The protein concentration was determined with the BCA Protein Assay Reagent (Pierce) using bovine serum albumin as standard. Supernatants were stored at $-20^{\circ} \mathrm{C}$ until used.

\section{TLC analysis of tomatinase reaction products.}

C. michiganensis subsp. michiganensis crude protein extracts and supernatants were tested for $\alpha$-tomatine degradation using the method of Lairini and associates (1996) with some modifications. A reaction mixture $(200 \mu \mathrm{l})$ containing $1 \mathrm{mM} \alpha$-tomatine, $20 \mathrm{mM}$ Na-acetate, $\mathrm{pH} 5.5,1 \mathrm{mM}$ dithiotreithol (DTT), and $500 \mu \mathrm{g}$ of isolated protein extract was incubated at $28^{\circ} \mathrm{C}$ for $22 \mathrm{~h}$. After incubation, the reaction mixture was vacuum dried, resuspended in $80 \mu \mathrm{l}$ of methanol, and $20 \mu \mathrm{l}$ each were separated on silica gel $60 \mathrm{~F}_{254}$ TLC plates (Merck, Darmstadt, Germany). The plates were developed in a solvent system consisting of ethyl acetate, methanol, acetic acid, and water (30:20:10:1, by volume). Spots were visualized after spraying with $50 \% \mathrm{H}_{2} \mathrm{SO}_{4}$ and heating to $110^{\circ} \mathrm{C}$ for 10 min. Reaction products were identified by cocomatography with standards ( $\alpha$-tomatine or tomatidine; Sigma, Deisenhofen, Germany) treated the same way. $\alpha$-Tomatine appeared as a black spot near the bottom line, whereas tomatidine was localized as a dark green spot near the solvent front.

\section{Toxicity test.}

TBY soft agar ( $3 \mathrm{ml}, 6 \%$ agarose) was mixed with $5 \mu \mathrm{l}$ of $C$. michiganensis subsp. michiganensis strains $\left(\mathrm{OD}_{580}\right.$ of approximately 6) and applied evenly as a top layer on TBY agar plates. Sterilized paper disks with a diameter of $6 \mathrm{~mm}$ containing defined amounts of $\alpha$-tomatine (resolved in Na-citrate, 50 $\mathrm{mM}, \mathrm{pH} 4.0$ ) were carefully applied on the top layer and incubated for 3 days at $26^{\circ} \mathrm{C}$. As negative control, paper disks containing only Na-citrate $(50 \mathrm{mM}, \mathrm{pH} 4.0)$ without $\alpha$-tomatine were used. Defined halos around the paper disks showed inhibition of growth by $\alpha$-tomatine.

\section{Virulence assays in planta.}

Two-week-old tomato plants (L. esculentum cv. Moneymaker) were infected by dipping the roots into freshly made bacterial suspensions $\left(\mathrm{OD}_{580}\right.$ of 8 to 10$)$ of Clavibacter strains for 15 min to enable infection by small vascular lesions through the root. Afterward, the infected plants were planted into sterilized earth and incubated at $25^{\circ} \mathrm{C}$ for $16 \mathrm{~h}(12,000 \mathrm{lux})$ and $19^{\circ} \mathrm{C}$ for $8 \mathrm{~h}$ in the dark with a relative humidity of 40 to $50 \%$ in a growth chamber. Each experimental group consisted of 32 plants. The virulent phenotype of Clavibacter strains was estimated by examining infected plants for wilting symptoms. Over a period of up to 28 days, plants were examined daily for the development of wilting symptoms (i.e., the occurrence of leaf curling). To get a more quantitative estimation of virulence, the wilting index, defined as the number of days required until $50 \%$ of the plants showed wilting symptoms, was determined (Meletzus et al. 1993). Finally, the titer of Clavibacter strains per gram of plant material after 28 days of incubation was determined. The plants were cut $1 \mathrm{~cm}$ above the ground and homogenized in a sterilized mortar under liquid $\mathrm{N}_{2}$. Serial dilutions of the homogenate were plated on TBY plates. Colonies were scored after incubation at $26^{\circ} \mathrm{C}$ for 5 days.

\section{ACKNOWLEDGMENTS}

This work was supported by a grant from the Deutsche Forschungsgemeinschaft (DFG) (EI 140/11-2). We are indebted to T. Thias for excellent technical assistance.

\section{LITERATURE CITED}

Altschul, S. F., Madden, T. L., Schäffer, A. A., Zhang, J., Zhang, Z., Miller, W., and Lipman, D. J. 1997. Gapped BLAST and PSI-BLAST: a new generation of protein database search programs. Nucleic Acids Res. 25:3389-3402.

Arwiyanato, T., Sakata, K., Goto, M., Tsuyumu, S., and Takikawa, Y. 1994. Induction of tomatine in tomato plant by an avirulent strain of Pseudomonas solanacearum. Ann. Phytopathol. Soc. Jpn. 60:288-294.

Beimen, A., Bermpohl, A., Meletzus, D., Eichenlaub, R., and Barz, W. 1992. Accumulation of phenolic compounds in leaves of tomato plants after infection with Clavibacter michiganense subsp. michiganense strains differing in virulence. Z. Naturforsch. C 47:898-909.

Bouarab, K., Melton, R., Peart, J., Baulcombe, D., and Osbourn, A. 2002. A saponin-detoxifying enzyme mediates suppression of plant defences. Nature 418:889-892.

Carlton, W. M., Braun, E. J., and Gleason, M. L. 1998. Ingress of Clavibacter michiganensis subsp. michiganensis into tomato leaves through hydathodes. Phytopathology 88:525-529.

El-Shanshoury, A. E.-R. R., El-Sououd, S. M. A., Awadalla, O. A., and ElBandy, N. B. 1995. Formation of tomatine in tomato plants infected with Streptomyces species and treated with herbicides, correlated with reduction of Pseudomonas solanacearum and Fusarium oxysporum $\mathrm{f}$. sp. lycopersici. Acta Microbiol. Pol. 44:255-266.

Friedman, M., and Levin, C. E. 1998. Dehydrotomatine content in tomatoes. J. Agric. Food Chem. 46:4571-4576.

Gartemann, K.-H., and Eichenlaub, R. 2001. Isolation and characterization of IS1409, an insertion element of 4-chlorobenzoate-degrading Arthrobacter sp. strain TM1 and development of a system for transposon mutagenesis. J. Bacteriol. 183:3729-3736.

Henrissat, B. 1991. A classification of glycosyl hydrolases based on amino 
acid sequence similarities. Biochem. J. 280:309-316.

Hopwood, D. A., Bibb, M. J., Chater, K. F., Kieser, T., Bruton, C. J., Kieser H. M., Lydiate, D. J., Smith, C. P., Ward, J. M., and Schrempf, H. 1985. Genetic manipulations of Streptomyces. A laboratory manual. John Innes Foundation, Norwich, U.K.

Howard, M. B., Ekborg, N. A., Taylor, L. E., Weiner, R. M., and Hutcheson, S. W. 2003. Genomic analysis and initial characterization of the chitinolytic system of Microbulbifer degradans strain 2-40. J. Bacteriol. 185:3352-3360.

Ito, S.-I., Eto, T., Tanaka, S., Yamauchi, N., Takahara, H., and Ikeda, T. 2004. Tomatidine and lycotetraose, hydrolysis products of $\alpha$-tomatine by Fusarium oxysporum tomatinase, suppress induced defense responses in tomato cells. FEBS (Fed. Eur. Biol. Soc.) Lett. 571:31-34.

Jahr, H., Dreier, J., Meletzus, D., Bahro, R., and Eichenlaub, R. 2000. The endo-beta-1,4-glucanase CelA of Clavibacter michiganensis subsp. michiganensis is a pathogenicity determinant required for induction of bacterial wilt of tomato. Mol. Plant-Microbe Interact. 13:703-714.

Kers, J. A., Cameron, K. D., Joshi, M. V., Bukhalid, R. A., Morello, J. E. Wach, M. J., Gibson, D. M., and Loria, R. 2005. A large, mobile pathogenicity island confers plant pathogenicity on Streptomyces species. Mol. Microbiol. 55:1025-1033.

Kirchner, O., Gartemann, K.-H., Zellermann, E.-M., Eichenlaub, R., and Burger, A. 2001. A highly efficient transposon mutagenesis system for the tomato pathogen Clavibacter michiganensis subsp. michiganensis. Mol. Plant-Microbe Interact. 14:1312-1318.

Kozukue, N., Han, J.-S., Lee, K.-R., and Friedman, M. 2004. Dehydrotomatine and a-tomatine content in tomato fruits and vegetative plant tissues. J. Agric. Food Chem. 52:2079-2083.

Laine, M. J., Nakhei, H., Dreier, J., Lehtilä, K., Meletzus, D., Eichenlaub, R., and Metzler, M. C. 1996. Stable transformation of the gram-positive phytopathogenic bacterium Clavibacter michiganensis subsp. sepedonicus with several cloning vectors. Appl. Environ. Microbiol. 62:1500-1506.

Lairini, K., Perez-Espinosa, A., Pineda, M., and Ruiz-Rubio, M. 1996. Purification and characterization of tomatinase from Fusarium oxysporum f. sp. lycopersici. Appl. Environ. Microbiol. 62:1604-1609.

Martin-Hernandez, A. M., Dufresne, M., Hugouvieux, V., Melton, R., and Osbourn, A. 2000. Effects of targeted replacement of the tomatinase gene on the interaction of Septoria lycopersici with tomato plants. Mol. Plant-Microbe Interact. 13:1301-1311.

Masahiro, A., Kouji, S., Toyomasa, A., Yamashoji, S., and Kenji, I. 1996. Measurement of tomatine content in tomatoes with bioassay procedure. J. Jpn. Soc. Food Sci. Technol. 43:275-280.

Meletzus, D., and Eichenlaub, R. 1991. Transformation of the phytopathogenic bacterium Clavibacter michiganense subsp. michiganense by electroporation and development of a cloning vector. J. Bacteriol. 173:184-190.

Meletzus, D., Bermpohl, A., Dreier, J., and Eichenlaub, R. 1993. Evidence for plasmid encoded virulence factors in the phytopathogenic bacterium Clavibacter michiganense subsp. michiganense NCPPB382. J. Bacteriol. 175:2131-2136
Osbourn, A. E. 1996. Preformed antimicrobial compounds and plant defense against fungal attack. Plant Cell 8:1821-1831.

Quidde, T., Osbourn, A. E., and Tudzynski, P. 1998. Detoxification of $\alpha$ tomatine by Botrytis cinerea. Physiol. Mol. Plant Pathol. 52:515-165.

Roldan-Arjona, T., Perez-Espinosa, A., and Ruiz-Rubio, M. 1999. Tomatinase from Fusarium oxysporum $\mathrm{f}$. sp. lycopersici defines a new class of saponinases. Mol. Plant-Microbe Interact. 12:852-861.

Ruiz-Roldan, M. C., Di Pietro, A., Huertas-Gonzales, M. D., and Roncero, M. I. G. 1999. Two xylanase genes of the vascular wilt pathogen Fusarium oxysporum are differentially expressed during infection of tomato plants. Mol. Gen. Genet. 261:530-536.

Saito, A., Fujii, T., and Miyashita, K. 2003. Distribution and evolution of chitinase genes in Streptomyces species: involvement of gene-duplication and domain-deletion. Antonie Leeuwenhoek 84:7-16.

Sambrook, J., Fritsch, E. F., and Maniatis, T. 1989. Molecular Cloning: A Laboratory Manual. Cold Spring Harbor Laboratory Press, Cold Spring Harbor, NY, U.S.A..

Sandrock, R. W., and VanEtten, H. D. 1998. Fungal sensitivity to and enzymatic degradation of the phytoanticipin alpha-tomatine. Phytopathology 88:137-143.

Sanger, F., Nicklen, S. and Coulson, A. R. 1977. DNA sequencing with chain-terminating inhibitors. Proc. Natl. Acad. Sci. U.S.A. 74:54635467.

Smith, C. A., and MacHardy, W. E. 1982. The significance of tomatine in the host response of susceptible and resistant tomato isolines infected with two races of Fusarium oxysporum f. sp. lycopersici. Phytopathology 72:415-419.

Smith, G. E., and Summers, M. D. 1980. The bidirectional transfer of DNA and RNA to nitrocellulose or diazobenzyloxymethyl-paper. Anal. Biochem. 109:123-129.

Strider, D. L. 1969. Bacterial canker of tomato caused by Corynebacterium michiganense. A literature review and bibliography. N. C. Agric. Exp. Stn. Tech. Bull. 193.

Tauch, A., Zheng, Z., Pühler, A., and Kalinowski, J. 1998. The Corynebacterium striatum resistance transposon Tn5564: Genetic organization and transposition in Corynebacterium glutamicum. Plasmid 40:126-139.

Thompson, J. D., Higgins, D. G., and Gibson, T. J. 1994. CLUSTAL W: improving the sensitivity of progressive multiple sequence alignment through sequence weighting, positions-specific gap penalties and weight matrix choice. Nucleic Acids Res. 22:4673-4680.

Vieira, J., and Messing, J. 1982. The pUC plasmids, an M13mp7 derived system for insertion mutagenesis and sequencing with synthetic universal primers. Gene 19:259-268.

Yanisch-Perron, C., Vieira, J., and Messing, J. 1985. Improved M13 phage cloning vectors and host strains: nucleotide sequences of the M13mp18 and pUC19 vectors. Gene 33:103-119.

Zverlov, V. V., Velikodvorskaya, G. V., Schwarz, W. H., Bronnenmeier, K., Kellermann, J., and Staudenbauer, W. L. 1998. Multidomain structure and cellulosomal localization of the Clostridium thermocellum cellobiohydrolase CbhA. J. Bacteriol. 180:3091-3099. 